\title{
Using Anther Culture Method for Flax Breeding Intensification
}

\author{
Andra Miķelsone ${ }^{1 ; 2}$, Dace Grauda ${ }^{1}$, Veneranda Stramkale ${ }^{3 ;}$, Reinis Ornicāns $^{1}$, \\ Isaak Rashal ${ }^{1}$ \\ 1 - Institute of Biology, University of Latvia, Miera Street 3, Salaspils, Latvia \\ 2 - Daugavpils University, Vienības Street 13, Daugavpils, Latvia \\ 3 - Agricultural Science Centre of Latgale, Kultūras sq. 1, Viḷāni, Rēzekne distr., Latvia \\ 4 - Rezekne Higher Education Institution, Scientific Institute for Regional Studies, Atbrivosanas aleja 90, \\ Rezekne, Latvia
}

\begin{abstract}
Flax breeding is a long and complicated process based on hybridization and following selection of the best plants. Because of possible occasional cross-pollination the development of genetically stable homozygous lines could last more than 15 years. For more rapid creating of initial material for flax breeding anther culture methods for producing doubled haploid (DH) lines could be used successfully. The goal of this study was to develop the best anther culture protocol for producing DH lines from hybrids included in Latvian flax breeding programme and to do preliminary field evaluation of obtained DH lines. $\mathrm{F}_{4}$ hybrids were used in the experiment. Method, most applicable for establishing of DH from anther cultures, was elaborated; $13 \mathrm{DH}$ lines were obtained during the experiment. Such agronomic important traits, as vegetation period, total plant height, number of seed vessels, number of seeds in a seed vessel, 1000 seeds weight, oil and bast fibre content were evaluated for obtained DH lines. Several accessions showed high 1000 seeds weight, number of seeds in a seed vessel, good oil and bast fibre content. It was concluded that anther culture method is of value of using as an adjunct to classical methods of flax breeding.
\end{abstract}

Keywords - agronomical traits, anther culture, doubled haploid lines, flax.

\section{INTRODUCTION}

Flax (Linum ustatissum L.) is one of the oldest cultivated plants in temperate regions. Flax is growing both as the oil and fiber crop. Seeds of oil flax recently became important constituent for many industrial applications, such as pharmacy, medicine, food production etc. and have high prospective for use in Latvia. Development of methods of obtaining flax varieties suitable for regional agriculture and industrial particularities is of high importance.

Flax is a self-pollinating plant with about $5-10 \%$ crossfertilization [1], [2]. Therefore, breeders mainly use pedigree selection, bulk breeding or progeny methods to develop new breeding lines and varieties [1], [3]. Major breeding objectives of Latvia flax breeding are creating early or mid-early ripening varieties with the improved yield (seed or fibre) and oil content, high fibre quality, resistance to lodging and diseases [4].

Traditional breeding methods are time consuming and take at least more than 15 years, therefore there is high demand for the use of alternative methods, such as producing homozygous doubled haploid (DH) lines [2], [3], [5], [6] which give a possibility speed up the breeding for several years [7]. Currently, anther culture is the most successful method for producing $\mathrm{DH}$ lines of flax [8], [9], [10].

Importance of different factors of success of establishment of anther culture and following development of plants-regenerants is known; most critical are genotype and growing conditions of donor plants, stage of microspore development, composition of the culture medium and temperature during the culture induction period [1], [11], [12].

The goal of this study was to develop the best anther culture protocol to producing $\mathrm{DH}$ lines from hybrids included in Latvian flax breeding programme and preliminary field evaluation of obtained DH lines.

\section{MATERIALS AND METHODS}

\section{Donor plants growing}

Hybrids of $\mathrm{F}_{4}$ generation of both oil and fibre flax (Table 1) were used for DH obtaining. Two different growing seasons of donor plants were applied: spring (sowing in March, buds collection during May-June) and summer (sowing in July, buds collection during AugustSeptember).

TABLE 1

FLAX $\mathrm{F}_{4}$ HYBRIDS USED FOR ANTHER CULTURE ESTBLISHMENT

\begin{tabular}{ll}
\hline Hybrids & Hybrid combination \\
\hline Fibre flax & \\
N1-1 & W196/Baltučai \\
N3-1 & Rigaer LIN 748-82/W-196 \\
N4-7 & Rigaer LIN 748-82/Nynke \\
N5-5 & Tverca/Nynke \\
\hline Oil flax & \\
E37/2 & Ceies/Norlin \\
E37/49 & Ceies/Norlin \\
E38 & Krupnosemjanij/Mikael \\
\hline
\end{tabular}


The donor plants were grown in a greenhouse with a temperature $24-28{ }^{\circ} \mathrm{C}$ in daytime and $15-18{ }^{\circ} \mathrm{C}$ during night time. All plants were grown in mixture of soil and peat $(2: 1)$ in $20 \mathrm{~cm}$ diameter pots, in each pot 30 plants were sowed.

\section{Buds collection and sterilization}

Buds were collected at the middle of late uni-nucleate stage of microspores. Buds were sterilized by $50 \%$ solution of commercial bleach (4\% of hypochlorite content) for $20 \mathrm{~min}$ and rinsed three times by sterile, deionized water. The developmental stage of microspores was determined by squashing in the acetic carmine on a glass slide [13].

For establishment of anther culture buds with length 5$7 \mathrm{~mm}$, width 1.5-3 mm, length of anther 1-2 mm, were collected. The length and width of buds were measured before sterilization, the length of anthers after it placing on induction medium was determined.

Three fibre flax hybrids (N1-1, N3-1, N4-7) (Table 1) were used to determine better buds and anthers size for anther culture establish. Correlation coefficients among size of buds or anthers and embryogenesis capacity were calculated by MS Excel.

\section{Cultivation on induction mediums}

Three oil flax hybrids (E37/2, E37/49 and E38) (table 1) were used to estimate influence of different anther culture induction mediums. For this purpose two different medium were used: Nichterlein (NC) induction medium [2] with $6 \%$ sucrose, $0.4 \%$ agarose, $\mathrm{pH} 5.5$; modified NLN82 medium [3] with 3\% sucrose, $0.4 \%$ agarose, $\mathrm{pH}$ 5.8. For fibre flax hybrids anther culture establish NLN82 medium were used. Petri dishes with anthers at $26{ }^{\circ} \mathrm{C}$ in the darkness were cultured.

Four fibre flax hybrids (N1-1, N3-1, N4-7, N5-5) (Table 1) were used for evolution of influence of cold stress. For this purpose $50 \%$ of anthers cultures were cultivated at $+4{ }^{\circ} \mathrm{C}$ for 24 hours. After cold treatment all cultures were cultivated at $26^{\circ} \mathrm{C}$ in the darkness.

\section{Cultivation on regeneration mediums}

Embryos obtained from two oil flax hybrids (E37/2 and E37/4) (Table 1) were used to estimate influence of different regeneration mediums on embryo regeneration capacity. All embryos witch formed generative calli were transferred on two different regeneration mediums: NC regeneration medium with $3 \%$ maltose, $0.8 \%$ gelrite, $\mathrm{pH}$ 5.8 [2], [12] and MS/B5 medium (MS medium mineral salts [14], B5 medium vitamins [15] with 3\% sucrose, $0.6 \%$ plant agar, supplemented by $1 \mathrm{mg} / \mathrm{l} \mathrm{BAP}, \mathrm{pH} 5.8$. Obtained embryos of other hybrids were cultivated only on MS/B5 medium with 3\% sucrose, $0.6 \%$ plant agar, supplemented by $1 \mathrm{mg} / \mathrm{l} \mathrm{BAP,pH} 5.8$ [16].

Cultures were grown in light conditions $\left(24^{\circ} \mathrm{C}, 16 \mathrm{~h} / 8 \mathrm{~h}\right.$ of day/night, light intensity $3000 \mathrm{~lx}$ ). The diameter of calli was determined after three weeks of cultivation on regeneration medium. Every four weeks calli were transferred onto fresh medium.

\section{Obtaining of plants- regenerants}

Shoots from different calli were transferred onto MS/B5 medium with $0.01 \mathrm{mg} / \mathrm{l} \mathrm{BAP}$ and $0.001 \mathrm{mg} / \mathrm{l}$ NAA from shoot elongation and rooting. Rooted plantlets were potted into autoclave-sterilised soil and incubated at $20{ }^{\circ} \mathrm{C}$. First days plantlets were covered with glass jars to maintain high humidity. The seeds of each regenerated plant were collected separately.

\section{Field evaluation}

$\mathrm{DH}$ lines were preliminary evaluated in field trials at the Agricultural Science Centre of Latgale. DH lines were sowed in plots ( 3 lines per plot). Between plots the long straw variety of oats were sowed to prevent the $\mathrm{DH}$ lines cross-fertilization. Colour of flower and agricultural important traits, such as flax total plant height, technical plant height, number of seed vessels, number of seeds in a seed vessel, 1000 seeds weight, oil and bast fibre content were recorded.

\section{RESULTS AND DISCUSSION}

\section{Influence of donor plants growing seasons on embryogenesis}

It was found that donor cultivation season has an influence on embryogenesis (Fig. 1). On average anther cultures established in spring (anthers were collected and transferred into in vitro in May) have higher embryogenesis (2-13 embryos on 100 anthers). Embryogenesis level of anthers, harvested from the summer-grown donor plants, was 1-6 embryos on 100 anthers. Similar results were published earlier elsewhere [17]: number of microspore-derived plants was significantly higher from anthers collected during January-July, than from those collected during AugustDecember.

In our experiment not only seasonal influence on embryo formation was visible, but also genotype and growing season interaction on embryos development was observed. Thus, for instance, for the hybrid N3-1 embryogenesis level of spring harvested anthers was $13 \%$, but for anthers harvested in summer - only $2 \%$. In the opposite, for the hybrid N1-1 embryogenesis level of spring harvested anthers was lower $(2 \%)$, than for summer harvested $(6 \%)$ of anthers (Fig. 1).

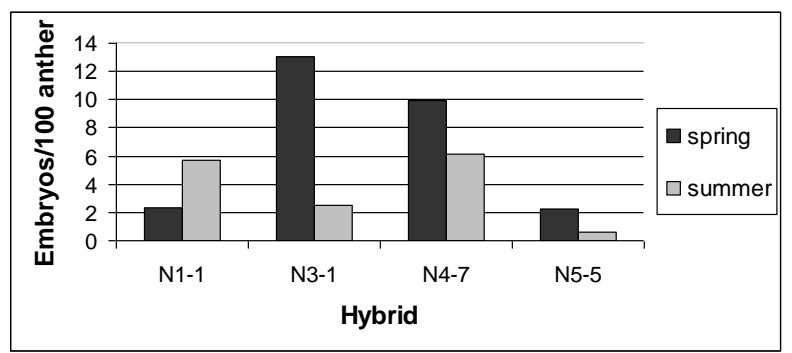

Fig. 1. Embryos formation from anthers depending of the season of donor plants growing. 
Buds and anthers size influence of embryo formation

It was found that the most suitable buds length for highest embryogenesis ranged from 5-6 $\mathrm{mm}$ for all genotypes used (Table 2). Hybrids N1-1 and N4-7 showed relatively high embryogenesis with $7 \mathrm{~mm}$ long buds. Buds of width $3 \mathrm{~mm}$ were not suitable for anther culture establishment: anthers obtained from these buds did not form any embryos. Embryogenesis was better for anthers, which were derived from the buds smaller in width $(1.5-2.5 \mathrm{~mm})$.

TABLE 2

ANTHER EMBRYOGENESIS DEPENDING OF BUDS AND ANTHER SIZE

\begin{tabular}{|c|c|c|c|}
\hline & \multicolumn{3}{|c|}{ Hybrids } \\
\hline & $\mathrm{N} 1-1$ & N3-1 & $\mathrm{N} 4-7$ \\
\hline Length of buds (mm) & \multicolumn{3}{|c|}{ Embryos/100 anthers } \\
\hline 5.0 & 11.3 & 6.7 & 11.8 \\
\hline 5.5 & - & 6.7 & - \\
\hline 6.0 & 2.3 & 3.3 & 5.9 \\
\hline 6.5 & - & 0 & - \\
\hline 7.0 & 3.3 & 0.7 & 3.9 \\
\hline \multicolumn{4}{|l|}{ Width of buds (mm) } \\
\hline 1.5 & - & - & 13.3 \\
\hline 2.0 & 7.0 & 3.5 & 6.4 \\
\hline 2.5 & 4.0 & 2.5 & 5.7 \\
\hline 3.0 & 0 & 0 & 0 \\
\hline \multicolumn{4}{|l|}{ Length of anther (mm) } \\
\hline 1.0 & 21.4 & - & 0 \\
\hline 1.5 & 3.8 & 2.8 & 12.6 \\
\hline 2.0 & 5.1 & 3.3 & 3.5 \\
\hline 2.5 & - & - & 0 \\
\hline
\end{tabular}

Anthers ranged from 1.5 till $2 \mathrm{~mm}$ were formed embryos for all genotypes. Embryogenesis from anthers with length $1 \mathrm{~mm}$ was observed only for the hybrid N1-1. No embryos were form from $2.5 \mathrm{~mm}$ anthers.

TABLE 3

CORRELATION COEFFICIENTS AMONG NUMBER OF EMBRYOS AND BUD/ANTHER SIZE FOR DIFFERENT FLAX HYBRIDS

\begin{tabular}{llll}
\hline & $\begin{array}{l}\text { Hybrids } \\
\mathrm{N} 1-1\end{array}$ & $\mathrm{~N} 3-1$ & $\mathrm{~N} 4-7$ \\
\hline $\begin{array}{l}\text { Length of buds / number } \\
\text { of embries }\end{array}$ & $-0.156^{* *}$ & $-0.110^{*}$ & $-0.138^{* *}$ \\
\hline $\begin{array}{l}\text { Width of buds / number } \\
\text { of embries }\end{array}$ & -0.091 & -0.080 & $-0.128^{*}$ \\
\hline $\begin{array}{l}\text { Length of anthers / } \\
\text { number of embries }\end{array}$ & $-0.181 * * *$ & 0.023 & $-0.217 * * *$ \\
\hline$* \mathrm{p} \leq 0.05 ; * * \mathrm{p} \leq 0.01 ; * * * \mathrm{p} \leq 0.001$ & & \\
\hline
\end{tabular}

Correlation coefficients among bud or anther size and embryogenesis and (Table 3) were statistically significant but very small. It could be explained by clear nonlinear relationship of the parameters of the interest.

\section{Influence of cold stress on embryogenesis}

Effect of the cold stress was not pronounced and varied depending from the genotype (Fig. 2): embryogenesis level for hybrids N1-1 and N3-1 was increased, but for hybrids N4-7 and N5-5, in the opposite, decreased. The influence of cold treatment was observed by several authors [10], [18], [19]. Mostly used cold stress temperatures ranged from $+4{ }^{\circ} \mathrm{C}$ till $+8{ }^{\circ} \mathrm{C}$. All of authors mentioned influence of genotype and duration of the treatment on embryogenesis level.

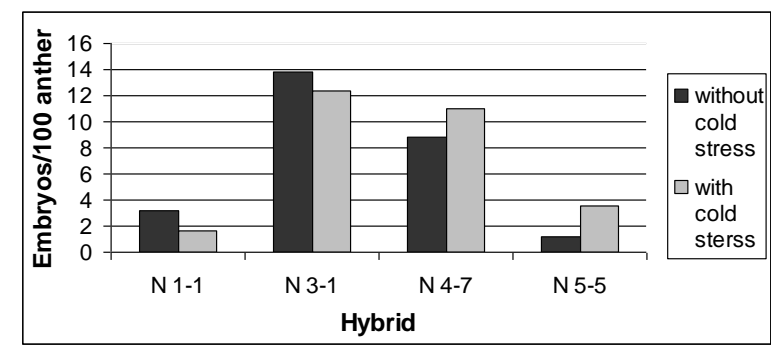

Fig. 2. Embryos formation from anthers depending of cold stress

Influence of induction medium on embryogenesis

Induction medium NLN82 was found as the most appropriate: anthers placed on this medium developed from 5 (E38) till 11 (E37/2) embryos on 100 anthers (Fig. 3). Embryogenesis on the NC induction medium ranged 3-4 embryos on 100 anthers. The genotype influences were observed: even genetically close hybrids E37/2 and E37/49, which derived from the same crossing combination, had different embryogenesis capacity on the medium NLN82, at the same time embryogenesis capacity of those hybrids on the NC induction medium was similar (Fig. 3)

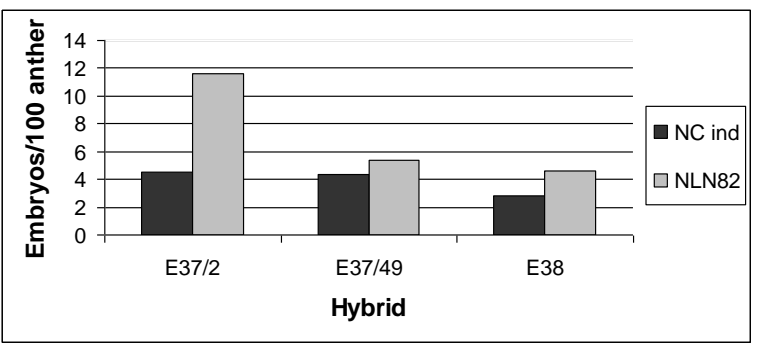

Fig. 3. Embryos formation from anther depending of induction medium

In continuation of the experiment with other hybrids the medium NLN82 was used as the induction medium. All obtained plants-regenerants were produced from calli, which had been grown on this induction medium.

\section{Influence of regeneration medium on calli regeneration capacity}

Development of the calli on regeneration medium is illustrated in Fig. 4. Better growth of calli was observed on the regeneration medium MS/B5 with BAP. The influence of genotype on calli growth on this medium was not observed. 


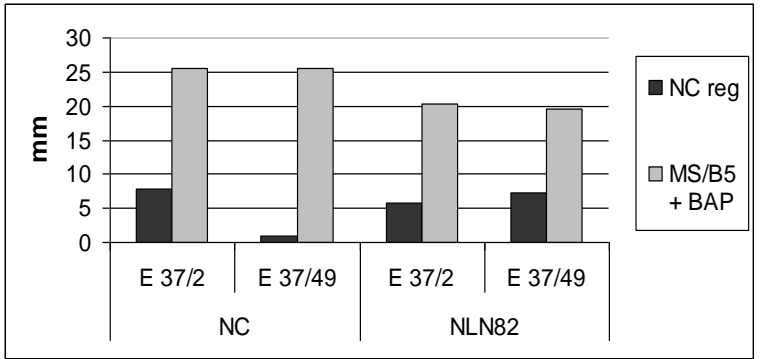

Fig. 4. Calli diameter $(\mathrm{mm})$ after four weeks of cultivation on the regeneration medium.

Calli cultivated on NC induction medium had grown less intensive. As appeared later, plants-regenerants were obtained only from calli grown on the induction medium NLN82, not depending of regeneration media (data not presented). It shows that for obtaining plants-regenerants important is not only composition of the regeneration medium, but even more crucial is the selection of used embryo induction medium.

\section{Field evaluation}

Several DH lines were tested in field trial to determine exhibition of some agronomical and biologically important traits. Vegetation period for all lines was 99 days. None of the lines showed presence of any flax diseases. Manifestation of other traits is presented in the Table 4.

All lines showed a relatively low total plant and technical height, but had a high content of bast fibre. Six DH lines had bast fibre content higher than $35 \%$ and only fibre content of the single line was lower than $30 \%$. It means that straws of $\mathrm{DH}$ lines are suitable for industrial processing for short flax fibre.

Number of seed vessels of tested DH lines was rather small, just 5 lines were with a seed vessels number of 10 or higher. Possible, it can be explained by particular growing conditions in this experiment, as flax plants were grown between rows of oats. However, number of seeds in a seed vessel, what is genotypically more determined, for all lines was above eight. A good indicator for the potential yield quality is the weight of 1000 seeds, which exceeded $5 \mathrm{~g}$, for $9 \mathrm{DH}$ lines it was higher even more than $6 \mathrm{~g}$. Since absence of sufficient quantity of seeds oil content could not be determined for all samples, therefore it was measured for 8 lines only, for all of them it varied $43-45 \%$, which is a good value.

\section{CONCLUSION}

The influence of different factors on embryo induction, development and plant-regenerants formation were found. Higher embryogenesis was observed when anthers were harvested from plants grown in the spring. Higher embryogenesis was observed on anther culture, which was derived from the buds in particular size: length - 5-6 mm, width - 1.5-2.5 mm. Cold treatment effect on anther culture was dependent on the used genotype. Better for embryogenesis and plantregenerants obtaining was NLN82 induction medium. Better calli regeneration capacity was observed on the regeneration medium $\mathrm{MS} / \mathrm{B} 5$ with BAP (1mg/l), and calli shoot formation was observed on this medium as well. Plants-regenerants were obtained when for embryo induction NLN82 medium and regeneration medium MS/B5 with BAP was used. Some DH lines were found with rather high baste fibre and oil content. All DH lines had a high weight of 1000 seeds. It means that obtained flax DH lines are suitable for further selection process of oilseed flax, for obtaining oil flax varieties with short fibre. Elaborated flax anther culture protocol is suitable for obtaining of DH lines to speed up the Latvian flax breeding program.

TABLE 4

FIELD CHARACTERISATION OF THE FLAX DH LINES

\begin{tabular}{|c|c|c|c|c|c|c|c|c|}
\hline \multirow{2}{*}{ DH line } & \multicolumn{2}{|c|}{ Plant height, $\mathrm{cm}$} & \multirow{2}{*}{$\begin{array}{l}\text { Bast fibre } \\
\text { content, } \\
\%\end{array}$} & \multirow{2}{*}{$\begin{array}{l}\text { Number of } \\
\text { seed } \\
\text { vessels }\end{array}$} & \multirow{2}{*}{$\begin{array}{l}\text { Number of } \\
\text { seed in seed } \\
\text { vessel }\end{array}$} & \multirow{2}{*}{$\begin{array}{l}1000 \text { seeds } \\
\text { weight, } \\
\mathrm{g}\end{array}$} & \multirow{2}{*}{$\begin{array}{l}\text { Oil content, } \\
\%\end{array}$} & \multirow{2}{*}{$\begin{array}{l}\text { Colour of } \\
\text { flower }\end{array}$} \\
\hline & Total & Technical & & & & & & \\
\hline ALE1 & 44.1 & 26.5 & 34.7 & 10.1 & 9.1 & 6.70 & 45.0 & Blue \\
\hline ALE2 & 42.8 & 24.8 & 20.9 & 9.9 & 8.8 & 5.99 & 43.2 & White \\
\hline ALE3 & 40.9 & 23.0 & 30.1 & 10.6 & 8.9 & 6.03 & 44.3 & Blue \\
\hline ALE4 & 28.4 & 17.2 & 32.4 & 5.4 & 8.4 & 6.72 & - & White \\
\hline ALE5 & 45.7 & 28.2 & 32.7 & 10.1 & 8.7 & 5.63 & 43.2 & White \\
\hline ALE6 & 28.2 & 17.4 & 34.9 & 6.0 & 8.6 & 6.84 & - & White \\
\hline ALE7 & 33.3 & 18.7 & 34.2 & 6.0 & 8.6 & 5.80 & - & White \\
\hline ALE8 & 39.0 & 22.6 & 34.8 & 9.2 & 9.0 & 6.85 & 43.7 & White \\
\hline ALE9 & 41.0 & 22.8 & 37.8 & 10.8 & 8.9 & 6.57 & 44.6 & Blue \\
\hline ALE10 & 40.8 & 22.4 & 35.5 & 10.0 & 8.6 & 6.51 & 44.4 & Blue \\
\hline ALE11 & 32.3 & 19.2 & 33.3 & 8.0 & 8.6 & 6.24 & 43.1 & White \\
\hline ALE12 & 38.2 & 23.4 & 34.7 & 7.4 & 8.1 & 5.31 & - & White \\
\hline ALE13 & 35.1 & 20.6 & 33.3 & 5.0 & 8.5 & 6.54 & - & White \\
\hline
\end{tabular}




\section{Mikelsone A., Grauda D., Stramkale V., Ornicāns R., Rashal I. USING ANTHER CULTURE METHOD FOR FLAX BREEDING INTENSIFICATION}

\section{ACKNOWLEDGMENTS}

Part of this work was financially supported by Latvian Council of Science Project Nr.10.0040: Investigation of Latvian renewable raw materials - flax and hemp products for development of innovative technologies and new functional materials, ESF project „Support for the implementation of doctoral studies at Daugavpils University" (Nr.2009/0140/1DP

/1.1.2.1.2/09/IPIA/VIAA/ 015) and project "Latvian field crop diversity evaluation and breeding optimisation by modern biotechnology methods" of the State Research Programme "Innovative technologies for high quality, safe and healthy food production from genetically, physiologically and biochemically diverse plant and animal raw material".

\section{REFERENCES}

[1] W. Friedt, "Breeding and agronomic development of linseed and sunflower for technical markets," in New crops for temperate regions, K. R.M. Anthony, J Meadley and G. Röbbelen, Eds., London: Chapman \& Hall, pp. 222-234, 1993.

[2] K. Nichterlein, "Anther culture of linseed (Linum usitatissimum L.)," in Doubled Haploid Production in Crop Plants. A manual, M. Maluszynski, K. Kasha, B.P. Forster and I. Szarejko, Eds., IAEA, 2003, pp. 249-254.

[3] R. Bergmann and W. Friedt, "Haploidy and related biotechnological methods in linseed (Linum usitatissimum L.)," in In Vitro Haploid Production in Higher Plants, Vol. 5, S. M. Jain, S. K. Sopory and R. E. Veilleux, Eds., Kluwer Academic Publishers, pp. 1-16, 1997.

[4] D. Grauda, V. Stramkale and I. Rašals, "Evaluation of Latvian flax varieties and hybrids," Proceedings in Agronomy, No. 6, pp. 159165,2004

[5] K. Nichterlein, H. Umbach and W. Friedt, "Genotypic and exogenous factors affecting shoot regeneration from anther callus of linseed (Linum usitatissimum L.)," Euphytica 58, pp. 157-164, 1991.

[6] N. Burbulis and A. Blinstrubiene, "Comparison of anther culture response among Linum usutatissimum $\mathrm{L}$. cultivars and their hybrids," Acta Universatis Latviensis Biology, vol. 710, pp. 131138,2006
[7] D. Grauda, N. Lepse,V. Strazdina, I. Kokina, L. Lapina, A. Mikelsone, L. Lubinskis and I. Rashal. "Obtaining of doubled haploid lines by anther culture method for the Latvian wheat breeding," Agronomy Research, Vol. 8 (Special Issue 3), pp. 545552, 2010.

[8] Y. Chen, E. Kenaschuk and P. Dribenki, "High frequency of plant regeneration from anther culture in flax, Linum usitatissimum L.," Plant Breeding 117, pp. 463-467, 1998.

[9] Z. Bartošavá, B. Obert, T. Takáč, A. Kormuták and A. Pretová, "Usimg enzyme polymorohism to identify the gametic origin of flax regenerants," Acta Biologica Crecoviensia Series Botanica 47/1, pp. 173-178, 2005.

[10] A. Pret'ová, B Obert and Z. Bartošová, "Haploid formation in maize, berley, flax and potato," Protoplasma 228, pp. 107-114, 2006.

[11] Y. Chen, E. O. Kenaschuk, and D. J. Procunier, "Plant regeneration from anther culture in Canadian cultivars of flax (Linum usitstissimum L.)," Euphytica 102, pp. 183-189, 1998.

[12] D. Grauda, I. Rashal and V. Stramkale, "The use in vitro methods for obtaining flax breeding source material," in Renewable Resources and Plant Biotechnology, R. Kozlowski, G. E. Zaikov and F. Pudel, Eds., Nova Publishers, pp. 127-134, 2006.

[13] C. Jacquard, G. Wojnarowiez and C. Clément, "Anther culture in barley," in Doubled haploid production in crop plants. A manual, M. Maluszynski, K.J Kasha, B.P. Forster and I. Szarejko, Eds., IAEA, pp. 21-27, 2003.

[14] T. Murashige and F. Skoog, "A revised medium for rapid Growth and bio assays with tobacco tissue cultures," Physiologia Plantarum, vol. 15, pp. 473-497, 1962.

[15] O. L. Gamborg, R. A. Miller and K. Ojima "Nutrient requirements of suspension cultures of soybean root cells," Experimental Cell Research, vol. 50, pp. 151-158, 1968.

[16] D. Grauda, A. Miķelsone and I. Rashal. "Use of antioxidants for enhancing flax multiplication rate in tissue culture," Acta Horticulturae, Nr. 812, pp. 147-151, 2009.

[17] B. Obert, Z. Žáčková, J. Šamaj and A. Pret'ová, "Doubled haploid production in Flax (Linum usitatissimum L.)," Biotehnology Advances 27, pp. 371-375, 2009.

[18] I. Rutkowska-Krause, G. Mankowska, M. Lukazewicz and J Szopa, "Regeneration of flax (Linum usitatissimum L.) plants from anther culture and somatic tissue with increased resistance to Fusarium oxysporum," Plant Cell Reports 22, pp110-116, 2003.

[19] B. Obert, B. Dadičová, A. Hricová, J. Šamaj and A. Pret'ová, "Flax anther culture: effect of genotype, cold treatment and media," Plant Cell, Tissue and Organ Culture 79, pp. 233-238, 2004. 